\title{
GAMBARAN AKTIVITAS FUNGSIONAL PENDERITA OSTEOARTHRITIS LUTUT YANG MENGGUNAKAN KNEE SUPPORT
}

\author{
Yulia Agitatik Mentari \\ Kementerian Kesehatan Politeknik Kesehatan Surakarta Jurusan Ortotik Prostetik
}

\begin{abstract}
Osteoarthritis, Functional Activity, Knee Support. Knee osteoarthritis is a chronic inflammation of the knee joint characterized by a decrease in muscle value and an impact on decreased knee joint stability resulting in decreased ability of a person to perform functional activities. The ability of functional activity is directly related to quality of life and its assessment is very important in clinical practice. The decrease in functional activity of knee osteoarthritis patient can be minimized by the use of knee support. The purpose of this study was to determine the effect of knee support on functional activity in patient with knee osteoarthritis. This study used qualitative research method with one subject of knee osteoarthritis. The result of this research there are some progress of the subject when performing functional activity that she could not do. The conclusion obtained is the use of knee support within six weeks can increase the functional activity of patients with knee osteoarthritis degree three. As for suggestions that can be given for researchers who want to continue this research is to add research subjects and also pay attention to uncontrolled factors cause knee osteoarthritis.
\end{abstract}

Key word : Osteoarthritis, Functional Activity, Knee Support.

Abstract : Osteoarthritis, Aktivitas Fungsional, Dukungan Lutut. Osteoarthritis lutut adalah peradangan kronis pada sendi lutut yang ditandai dengan penurunan nilai otot dan berdampak pada menurunnya stabilitas sendi lutut yang mengakibatkan menurunnya kemampuan seseorang untuk melakukan aktivitas fungsional. Kemampuan aktivitas fungsional secara langsung berkaitan dengan kualitas hidup dan penilaiannya sangat penting dalam praktik klinis. Penurunan aktivitas fungsional pasien osteoarthritis lutut dapat diminimalkan dengan penggunaan dukungan lutut. Tujuan dari penelitian ini adalah untuk mengetahui pengaruh dukungan lutut pada aktivitas fungsional pada pasien dengan osteoarthritis lutut. Penelitian ini menggunakan metode penelitian kualitatif dengan satu subjek osteoartritis lutut. Hasil dari penelitian ini ada beberapa kemajuan subjek ketika melakukan aktivitas fungsional yang dia tidak bisa lakukan. Kesimpulan yang didapat adalah penggunaan dukungan lutut dalam waktu enam minggu dapat meningkatkan aktivitas fungsional pasien dengan osteoartritis lutut derajat tiga. Adapun saran yang dapat diberikan bagi peneliti yang ingin melanjutkan penelitian ini adalah dengan menambah subyek penelitian dan juga memperhatikan faktor yang tidak terkontrol penyebab osteoartritis lutut.

Kata Kunci: Osteoarthritis, Aktivitas Fungsional, Dukungan Lutut. 


\section{PENDAHULUAN}

Perkembangan

pembangunan disegala bidang kehidupan menyebabkan perubahan dalam tingkah laku dan pola hidup masyarakat sehingga menimbulkan dampak berbagai macam gangguan kesehatan (Pristi, 2014). Menurut World Health Organization (WHO, kehidupan sekian ratus juta orang terganggu akibat gangguan tulang / sendi. Gangguan berupa degenerasi yang dimulai usia 40 tahun dan mayoritas (90\%) pada sendi penumpu berat badan. Salah satu gangguan persendian yang berperan menurunkan abilitas manusia adalah osteoartritis pada lutut dengan penderita 151 juta jiwa di seluruh dunia dan mencapai 24 juta jiwa di kawasan Asia Tenggara (Annas, 2015).

Osteoarthritis merupakan radang kronis sendi yang ditandai dengan kerusakan tulang rawan pelapis persendian (Alexander, 2013). Gesekan yang berakibat destruksi akan berujung pada penipisan di ujung - ujung tulang keras pembentuk sendi dan menyebabkan rasa nyeri terutama saat sendi digerakkan sehingga pasien membatasi pergerakkan pada lutut yang mengalami osteoartritis (Charles, 2016).

Tetapi istirahat lama akan menyebabkan sendi kaku dan kontraksi otot menjadi terbatas (Verma, 2005). Penyebab utama dari osteoarthritis masih idiopatik yang mana penyebabnya belum diketahui dan tidak ada hubunganya dengan penyakit sistemik, inflamasi ataupun perubahan lokal pada sendi (Evelyn, 2002).

Tingkat keparahan osteoarthritis meningkat seiring dengan bertambahnya usia seseorang dimana keadaan otot - otot di sekeliling sendi mulai melemah. Kelemahan otot dapat berkurang disebabkan oleh faktor inaktivasi akibat nyeri atau karena adanya peradangan pada sendi (Soeroso, 2006).

Penyempitan bagian medial/lateral pada lutut umumnya menjadi penyebab ketidaknyaman dan nyeri pada kebanyakan orang dewasa/lanjut yang disebabkan oleh osteoarthritis (Vladamir, 2003). Pada umunya penderita osteoarthritis mengalami gangguan fungsional karena mengeluhkan nyeri pada saat lutut menumpu selama stance phase yang dimulai pada saat heel strike hingga toe off (S.Th.Susilowati dkk, 2012). Analisa biomekanik orang sehat mengungkapkan bahwa beban pada lutut selama berdiri bagian medial $62 \%$ dan bagian lateral $38 \%$. Seseorang yang mengalami deformitas varus akibat adanya arthritis sendi lutut penumpuan beban di bagian medial menjadi $100 \%$ dari total beban yang diterima lutut selama fase ini (Self et al, 2000).

Kekuatan otot mengalami penurunan tiga persen per minggu dan kemunduran nilai otot akan berdampak pada penurunan stabilitas sendi dan penurunan kemampuan sendi untuk meredam beban tubuh sehingga menyebabkan menurunnya kemampuan seseorang untuk melakukan akivitas fungsional (Taufiq, 2015).

Aktivitas fungsional merupakan setiap gerakan tubuh, dihasilkan oleh otot rangka yang memerlukan pengeluaran energi dimana kapasitas fisik yang dimiliki guna untuk memenuhi kewajiban hidupnya, yang berintegrasi/ berinteraksi dengan lingkungan dimana ia berada (Binkley, 1999). Aktivitas pergerakkan normal sangat diperlukan dalam menunjang kegiatan sehari - hari supaya menjadi manusia yang mandiri (Jussi, 2017). 
Profesional kesehatan sering menggunakan kemampuan seseorang atau ketidakmampuan untuk melakukan aktivitas sehari - hari sebagai pengukuran status fungsional mereka, terutama berkenaan dengan orang-orang yang mengalami disabilitas, cidera atau karena menuanya usia (Yong, 2009).

Upaya untuk menurunkan disabilitas dapat dilakukan dengan pemakaian penguat pada lutut berupa alat orthosis yaitu knee support (Shirley, 2016). Menurut Emily (2013) knee support merupakan sebuah alat bantu untuk penderita osteoarthritis lutut yang di pasangkan pada lutut, berfungsi untuk memberikan perlindungan pada ligamen dan untuk mempermudah pergerakan.

Knee support yang akan digunakan dalam penelitian ini terbuat dari bahan elastic sehingga berfungsi sebagai fiksasi pada lutut yang mengalami osteoarthritis dengan penguat/penyangga pada bagian medial atau lateral yang terbuat dari logam dan berfungsi sebagai support dan stabilisator sendi lutut yang mengalami osteoarthritis (Dani, 2017). Dengan adanya fiksasi pada lutut serta support dan stabilisator pada sendi lutut akan meredakan nyeri pada penderita osteoarthritis lutut sehingga diharapkan dapat meningkatkan aktivitas fungsional sehari - hari (Agusni, 2013).

\section{METODE PENELITIAN}

Penelitian ini menggunakan penilitian kualitatif. Penelitian kualitatif menghasilkan mengolah data yang bersifat deskriptif. Dalam penelitian ini, penulis ingin memberikan deskripsi mengenai perubahan beberapa aspek pada aktivitas fungsional penderita osteoarthritis lutut yang menggunakan knee support, dan tidak ada hipotesis yang diuji, meskipun menggunakan teori yang ada.

Pendekatan penelitian adalah murni kualitatif dengan menggunakan metode-metode kontak langsung, yakni wawancara. Peneliti akan melakukan penelitian kualitatif dengan metode pengumpulan data secara wawancara terfokus (Poerwandari, 2009). Efektivitas penggunaan knee support terhadap aktivitas fungsional penderita osteoarthritis lutut akan diteliti dari data konkrit. Dimana subjek penelitian ini adalah penderita osteoarthritis lutut dengan cara wawancara terfokus pada penderita osteoarthritis lutut.

Penelitian ini menggunakan tipe studi kasus. Tipe studi kasus adalah fenomena khusus yang hadir dalam suatu konteks yang terbatasi (bounded context), meski batas-batas antara fenomena dan konteks tidak sepenuhnya jelas (Sugiyono, 2016). Kasus itu dapat berupa individu, peran, kelompok kecil, organisasi, komunitas, atau bahkan suatu bangsa. Studi kasus deskriptif lebih memperhatikan deskripsi secara detail dari fenomena dalam konteksnya (Moleong, 2000). Dalam penelitian ini, fenomena khusus yang hadir adalah penggunaan knee support pada penderita osteoarthritis lutut.

Tipe studi kasus yang digunakan dalam penelitian ini adalah studi kasus intrinsik. Penelitian dilakukan karena ketertarikan atau kepedulian pada suatu kasus khusus. Penelitian dilakukan untuk memahami secara utuh tentang kasus tersebut tanpa harus dimaksudkan untuk menghasilkan konsep - konsep teori ataupun tanpa ada upaya menggeneralisasi (Poerwandari, 2009). Pada studi kasus intrinsik, peneliti mempunyai ketertarikan atau kepedulian pada kasus ini (Wilig, 2001 ), yaitu 
perubahan beberapa aspek pada aktivitas fungsional penderita osteoarthritis lutut yang menggunakan knee support tanpa menghasilkan konsep-konsep atau teori, ataupun tanpa upaya menggeneralisasi.

Pada penelitian ini menggunakan metode wawancara, observasi langsung, dokumen pribadi (rekam medika penderita osteoarthritis lutut dan hasil terapi yang dinilai setiap kali penderita osteoarthritis lutut melakukan aktifivitas fungsional).

Menurut Banister (dalam Poerwandari, 2007), wawancara adalah percakapan dan tanya jawab yang diarahkan untuk mencapai tujuan tertentu.

Peneliti akan melakukan wawancara dengan pedoman wawancara yang terbuka. Pedoman wawancara ditulis secara umum, dengan pertanyaan dan penjabarannya yang bersifat fleksibel dalam kalimat. Peneliti akan melakukan wawancara langsung kepada penderita osteoarthritis lutut. Pertanyaan wawancara terdiri atas pertanyaan tentang kondisi aktivitas fungsional subjek sebelum menggunakan knee support dan pertanyaan tentang kondisi aktivitas fungsional subjek setelah menggunakan knee support.

\section{HASIL PENELITIAN}

Dalam analisa ini terdapat gambaran umum subjek, hasil observasi pelaksanaan penggunaan knee support, dan hasil wawancara dengan penderita osteoarthritis lutut tentang kondisi sebelum dan sesudah penggunaan knee support.

Subjek dengan nama WS adalah perempuan, lahir tanggal 20 Januari 1963. Subjek sering merasakan nyeri di area sendi lutut selama seminggu, hal ini yang mendasari subjek untuk berobat dan didapatkan diagnosa osteoarthritis lutut dari Rumah Sakit Ortopedi Dr Soeharso saat berusia 54 tahun 10 bulan. Subjek belum menggunakan knee support sebelum menjadi subjek penelitian ini. Ketika nyerinya kambuh, subjek hanya mengkonsumsi obat pereda nyeri yang diresepkan dari Rumah Sakit Ortopedi Dr Soeharso dan harus beristirahat.

Subjek bekerja menjadi guru matematika di SDN Makam Haji 03 Sukoharjo. Untuk kegiatan mengajar subjek sering melakukannya dengan berdiri daripada duduk, ketika subjek kesulitan untuk melakukan aktivitas mengajar di depan kelas dengan berdiri karena nyeri lutut nya kambuh subjek akan mengajar dengan duduk dan keadaan kelas akan menjadi kurang kondusif. Tempat subjek bekerja memiliki bangunan dua lantai, tidak jarang subjek selalu berhenti sejenak ditengah-tengah perjalanan saat menaiki dan menuruni tangga. Jarak tempat tinggal subjek dengan tempat kerja $\pm 50 \mathrm{~m}$, sehingga untuk berangkat dan pulang subjek berjalan kaki.

Kegiatan sehari - hari subjek di rumah tidak terlalu berat karena dibantu dengan pembantu rumah tangga yang menginap di rumahnya. Subjek kesulitan saat menaruh dan mengambil barang dari lantai, subjek harus duduk terlebih dahulu untuk menaruh dan mengambil barang dari lantai. Subjek sama sekali tidak bisa berjongkok sehingga subjek selalu menggunakan toilet dengan closet duduk. Subjek juga kesulitan berlari pada permukaan tanah yang tidak rata maupun permukaan tanah yang rata. Subjek biasa melakukan olahraga ringan seperti jalan jalan pagi setelah sholat subuh di area komplek rumahnya. Subjek juga rutin mengikuti senam pra lansia setiap hari 
minggu pukul 06.00 di balai desa Makam Haji namun banyak sekali gerakan dalam senam tersebut yang tidak dapat diikuti dengan baik oleh subjek seperti gerakan berlari ditempat, membungkukkan badan dan ujung tangan menyentuh tanah, berdiri dengan satu kaki.

\section{PEMBAHASAN}

Dari hasil observasi penggunaan knee support yang dilakukan oleh ortotis prostetis, dulunya subjek mengalami beberapa kesulitan dalam melakukan aktivitas fungsional seperti halnya berdiri dalam waktu yang lama, menaiki dan menuruni tangga, menaruh dan mengambil barang dari lantai, berjongkok, berlari pada permukaan tanah yang tidak rata maupun permukaan tanah yang rata, tidak dapat mengikuti dengan baik setiap gerakan pada senam pra lansia.

Setelah penggunaan knee support dilakukan saat subjek melakukan aktivitas dalam kurun waktu enam minggu, mulai terlihat adanya peningkatan aktivitas fungsional subjek.

Kemajuan yang terlihat pada kegiatan subjek di tempat kerja seperti aktivitas mengajar dimana subjek sekarang mampu untuk berdiri saat memberikan pelajaran kepada siswa siswi nya di depan kelas dalam kurun waktu 45 menit tanpa harus jeda duduk sebentar. Subjek mampu untuk menaiki dan menuruni tangga tanpa harus berhenti sejenak ditengah - tengah perjalanan.

Kemajuan yang terlihat pada kegiatan sehari - hari subjek di rumah seperti hal nya sekarang subjek mampu untuk menaruh dan mengambil barang dari lantai tanpa harus duduk terlebih dahulu, meski sekarang subjek masih belum bisa untuk menggunakan closet duduk namun subjek sekarang mampu untuk berjongkok dalam kurun waktu 25 detik.Subjek sekarang mampu untuk berlari kecil - kecil di permukaan tanah yang rata dalam jarak 20 meter namun subjek masih kesulitan dalam berlari kecil - kecil pada permukaan tanah yang tidak rata. Saat mengikuti senam pra lansia subjek mampu untuk berlari di tempat dalam waktu 15 detik dari waktu 60 detik yang ditentukan oleh instruktur senam, subjek mampu untuk membungkukkan badan namun ujung tangan masih belum bisa menyentuh tanah, subjek mampu untuk berdiri dengan satu kaki yang normal dan untuk berdiri dengan satu kaki yang mengalami osteoarthritis lutut subjek mampu melakukannya dalam waktu 5 detik.

\section{KESIMPULAN DAN SARAN}

Berdasarkan hasil observasi, wawancara dan analisa yang dilakukan terhadap penatalaksanaan penggunaan knee support dalam kurun waktu enam minggu, maka dapat disimpulkan bahwa penggunaan knee support dapat meningkatkan aktivitas fungsional pada penderita osteoarthritis lutut derajat tiga.

Adapun saran yang dapat diberikan oleh peneliti yang ingin melanjutkan penelitian ini adalah agar menambahkan subjek penelitian dan juga memperhatikan faktor - faktor yang tidak terkontrol penyebab osteoarthritis lutut. Penelitian ini diharapkan juga bisa menambah khasanah pengetahuan mengenai intervensi aktivitas fungsional pada penderita osteoarthritis lutut berupa pemberian knee support.

\section{DAFTAR RUJUKAN}

Agusni, K (2013). Penggunaan Knee Brace Menghambat Deformitas Pada Osteoartritis. Poltekkes 
Kemenkes Jakarta 1, Jakarta, 9-15. Alexander et al (2013). A Review on the Management of Hip and Knee Osteoarthritis. University of Glasgow Medical School, United Kingdom, 1-11.

Annas, S (2015). Hubungan Obesitas dengan Terjadinya Osteoarthritis Lutut Pada_Lansia Kecamatan Laweyan Surakarta. Universitas Muhammadiyah Surakarta, Surakarta, 3-11.

Binkley et al (1999). The Lower Extremity Functional Scale (LEFS): Scale Development Measurement Properties, and Clinical Application. Atlanta, Inggris, 79 (4), 371-383.

Cartwright, C.A, \& Cartwright, P,G (1984). Developing Observation Skills $2^{\text {nd }}$ ed. USA, Mc GrawHill.

Charles, J.M (2016). The Medical Therapy of Osteoarthritis: Thinking Outside the Box. University Hospitals Case Medical Centre, USA, 1(1), 1-5.

Dani, A (2017). Pengaruh Penggunaan Knee Orthosis_terhadap Penurunan Derajat Nyeri pada Cedera Lutut (Knee Joint) karena Olahraga. Poltekkes Kemenkes Surakarta, Surakarta, 8-35.

Emily et al (2013). Unloader Knee Support for Osteoarthritis: Do Patients Actually Wear Them. University of Washington School of Medicine, USA, 471, 1980 1989.

Evelyn, C (2002). Anatomi dan Fisiologi untuk Paramedis. Gramedia, Jakarta, 44-65.

Jussi et al (2017). Reliability and Validity of the Finnish Version of the Lower Extremity Functional Scale
(LEFS). England, 39(12), 12281234.

Moleong, J. L (2000). Metodologi Penelitian Kualitatif. Edisi Revisi, PT. Remaja Rosdakarya, Bandung.

Poerwandari, E. K (2009). Pendekatan Kualitatif untuk Penelitian Perilaku Manusia. LPSP3 Universitas Indonesia, Depok.

Pristi, A (2014). Pengaruh Pemakaian Knee Support Terhadap Intensitas Nyeri pada Penderita Osteoarthritis Lutut Stadium 3 di Rumah Sakit Orthopedi Prof. Dr. R. Soeharso. Poltekkes Kemenkes Surakarta, Surakarta, 7-30.

Self et al (2000). Biomechanical analysis of a medial unloading brace for osteoarthritis in the knee. USA, 14(4), 191-197.

Shirley et al (2016). Effectiveness of Knee Bracing in Osteoarthritis: Pragmatic Trial in a Multidisciplinary Clinic. Sydney, Australia, 19, 279-286.

S.Th.Susilowati dkk (2012). Penggunaan Knee Support Plat $2 \mathrm{~mm}$ dengan Knee Support Plat $4 \mathrm{~mm}$ dan Progresivitas Nyeri Lutut. Poltekkes Kemenkes Surakarta, Surakarta, 17-23.

Soeroso dkk (2006). Osteoartritis. Edisi empat, Jakarta, 40101.

Sugiyono (2016). Metode Penelitian Kualititatif dan $R \&$ D. PT Alfabet, Bandung.

Taufiq, A (2015). Pengaruh Penguluran Otot Hamstring Terhadap Peningkatan Aktivitas Fungsional Pada Lansia Penderita Osteoarthritis Knee di Panti Wreda Darma Bhakti Surakarta. Universitas Muhamaddiyah 
Surakarta, Surakarta, 3-16.

Verma et al (2005). Osteoarthritis. JAPI, India, 53, 634-641.

Vladamir et al (2003). Osteoarthritis: Understanding the Pathophysiology, Genetics, and Treatments. John Hopkins School of Medecine, USA, 95, 475-483.

Wilig, C (2001). Introducing Qualitative Research in Psychology: Adventure in Theory and Method. United Kingdom, Open University Press.

Yong et al (2009). The Lower Extremity Functional Scale could be an alternative to the Western Ontario and McMaster Universities Osteoarthritis Index Physical Function Scale. Elsevier, 62 (10), 1103-1111. 